\title{
Daily HRV assesment evaluated by remote control in dementia
}

\author{
G. Raimondi ${ }^{1}$, N. Marchitto ${ }^{2}$, B. Scordamaglia ${ }^{1}$, A. Ciaramella ${ }^{1}$ \\ P. Casacci ${ }^{3}$, M. Pistoia ${ }^{3}$, S. Sacco ${ }^{1}$, G. Sancesario ${ }^{4}$ \\ ${ }^{1}$ University of Roma «Sapienza», Italy \\ ${ }^{2}$ ASL Latina, Italy \\ ${ }^{3}$ Liferesult, Italy \\ ${ }^{4}$ University «Tor Vergata», Roma, Italy
}

\begin{abstract}
Introduction.The use of technology as a support and medical attention to different types of diseasesis now a common feature in several research projects conducted at European and national level. Diseases such as Alzheimer's or stroke, considered among the leading causes of disability are at the center of these projects.

Aim. The aim of this study has been to evaluate the ability to monitor the daily autonomic assessment in patients with dementia by means the HRV analysis of ECG signal recorded with a new device: the «Pulse» that is a wearable electronic device for the acquisition, recording and transmission of physiological parameters to external devices.

Materials and Methods. We studied 36 patients ( $17 \mathrm{~F}$ and $19 \mathrm{M}, 73,9 \pm 8,9$ years). At the patients we installed a «Pulse» for a week. From the pulse we can obtain a record for 5-minute each hour in which the ECG, breath frequency, body position and activity level are reported.

Results. With these preliminary data we obtained 3 important results: first, in all the patients enrolled we did not observe any change of electrical conduction on the ECG signals. Second the cardiovascular variability is very low in all period considered. In fact the principal indexes of the HRV showed a reduction. Finally, in each period considered the both linear in the frequency domain and non linear indexes of the sympathetic activity, showed a marked increase specially during the night period.

Conclusion. The proposed system can help the physician and the caregiver in the control of these patients with dementia. The wireless connection allowed various of device application and several monitoring arrangements ranging from real-time monitoring to long-term recording of biological signals. Implementation of this model may facilitate both accessibility and availability of personalized monitor and therapy. Further studies would validate it in the clinical and healthcare environment.
\end{abstract}

Key words: Telemedicine; HRV; Dementia.

๑2018 Institute Medical Informatics and Telemedicine Ltd, ${ }^{\circ} 2018$ Ukrainian Association for Computer Medicine, ${ }^{\odot} 2018$ Kharkiv medical Academy of Postgraduate Education. Published by Institute of Medical Informatics and Telemedicine Ltd. All rights reserved.

ISSN 1812-7231 Klin. inform. telemed. 2018, vol. 13, iss. 14, pp. 47-51. https://doi.org/10.31071/kit2018.14.06 http://kit-journal.com.ua/en/index_en.html

References (16)

\section{Introduction}

The use of technology as a support and medical attention to different types of diseasesis now a common feature inseveral research projects conducted at European and national level. Diseases such as Alzheimer's or stroke, considered among the leading causes of disability are at the center of these projects.

In the Integrated Management of the disease, the patient and his family are the center of a network which includes specialized outpatient services, day centers, home care services, the nursing homes (RSA), the long-term care and the hospital.

The Integrated Management is made easier by the use of electronic health records, which allow the sharing of patient information from all those involved.

The literature presents some experimental devices of telehealth that, although they are related to small samples, stimulate important reflections.

With reference to diseases related to cognitive deficits, the thechnology research is oriented substantially in various directions: that of supporting remote management of drug therapy, the control of the patient's conditions, and that of the support at home through the administration of telematics rehabilitation programs.

For example particular attention is required when prescribing psychotropic medications in patients with Alzheimer Disease (AD) or other dementia, because sometimes induce serious iatrogenic effects but preventable. Since acetylcholine is the main neurotransmitter in the parasympathetic nervous system, it is assumed that the cholinergic activity of acetylcholinesterase inhibitors and the anticholinergic properties of the antipsychotics agents are both related to the vagal modulation, that can be observed from the surveys of the electrocardiogram (ECG).

We hypothesize that the early ECG recording with remote control can be predictive of the side effects of treatment with neuroleptics and with acetylcholinesterase inhibitors.

The aim of this study has been to evaluate the ability to monitor the daily autonomic assessment in patients with dementia by means the HRV analysis of ECG signal recorded with a new device: the «Pulse» that can acquire, digitalize, storein a tablet or smartphone device and periodically transmits via a Bluetooth radio link with a host device, connected to a medical. 


\section{Material and Methods}

The Pulse: the Pulse Sensor (MR\&D) is a wearable, battery operated device intended for use as a part of a multiparameter analysis system. It uses a component adhesive sensorized (plaster), placed on the body of the person assisted, that is connected to other electronic components included in the device.

The pulse permits to record heart rate, respiratory rate and the level of activity of the person providing the management system of continuous or periodic messages of information to/from the server according to the specific settings defined by operators.

The Pulse supports 6 different medical protocols: Based on the physiological data computed or Real-time check through data fusion.

When a protocol is violated a notification is sent to the external device: The notification includes the time stamp for the violation, so the external device can request the raw signals for that specific moment.

The settings for each medical protocol are completely configurable:

1. Each protocol can be enabled/disabled independently.

2. Checking frequency is configurable.
3. Thresholds are configurable.

4. Notifications can be suppressed according to configurable rules (e. g.: identical, repeated notifications can be suppressed/reduced.

Available data and parameters depends on the selected operative mode. In fact the Pulse can be configured to operate in 2 different modes:

- Streaming Mode: is when the Pulse is powered ON and sampling the data as specified in the Configuration Settings, sending them directly to the Associated Device with periodicity specified by the last configuration commands received from the Associated Device.

- Monitoring mode: is when the Pulse is powered ON, gathering and storing in the internal memory data at the frequency specified in the Configuration Settings, and sending the data as requested by the Associated Device.

From the pulse we can obtain a record for 5 -minute each hour in which the ECG (signal and R-R interval), breath frequency, position and activity level are reported; then in the day we can observe 24 records and we have the possibility to have not only the ECG abnormalities (arrhythmias or conduction's defects) but also the neurovegetative assessment during the normal activity.
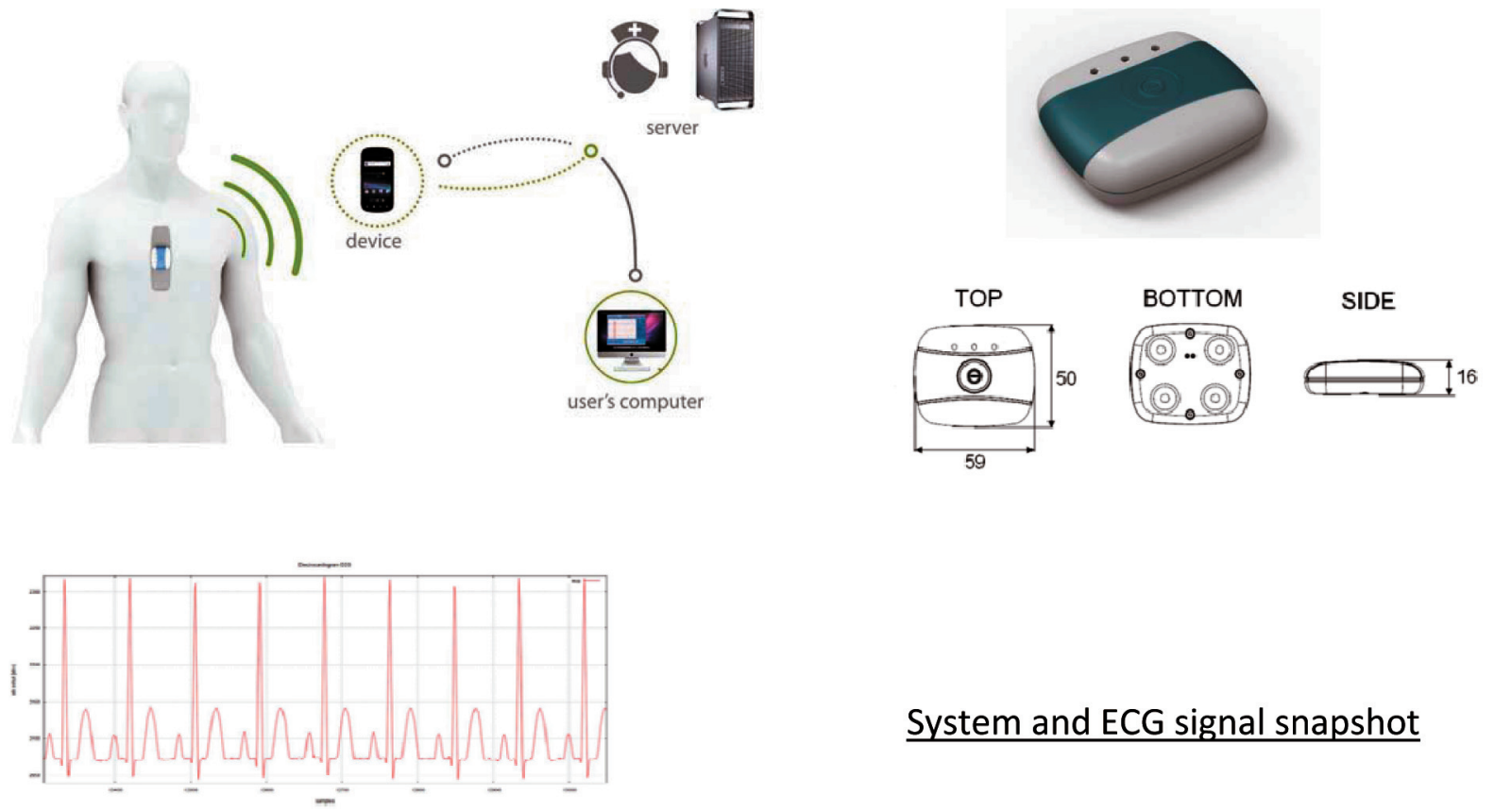

System and ECG signal snapshot

\begin{tabular}{|l|c|c|}
\hline \multicolumn{1}{|c|}{ Signals and Parameters } & Streaming Mode & Monitoring mode \\
\hline ECG raw & $128 / 256 \mathrm{~Hz} / 256 \mathrm{~Hz}$ \\
\hline Heart Rate & 1 each $10-15-30-60$ secs & 1 each $10-15-30-60$ secs \\
\hline Heart Rate Reliability & 1 each 10 secs & 1 each 10 secs \\
\hline R-R Variability & 1 each 10 secs & 1 each 10 secs \\
\hline XYZ raw & $50,0 \mathrm{~Hz}$ & - \\
\hline Activity level & 1 each $5-10-15-30-60$ secs & 1 each $5-10-15-30-60$ secs \\
\hline BIOIMP-ZO raw & $32 \mathrm{~Hz}$ & - \\
\hline BIOIMP-DZ raw & $32 \mathrm{~Hz}$ & 1 each 15-30-60 secs \\
\hline Respiration Rate & 1 each $15-30-60$ secs & 1 each $10-15-30-60$ secs \\
\hline Battery Level & 1 each $10-15-30-60$ secs & - \\
\hline
\end{tabular}


In fact, from the records we can extrapolate by means KUBIOS-HRV software the HRV analysis, both linear and non linear. Linear methods include traditional statistical analysis (SDNN, RMSSD) and the analysis of the HRV through the frequency domain calculating the LF, HF and LF/HF Ratio components. Nonlinear methods include the Poincarè plot (SD1 and SD2 indexes) and the Detrended Fluctuation Analysis (DFA $-\alpha 1$ and $\alpha 2$ indexes).

We have chosen the six most representative periods of the day, but, of course it is possible to evaluate not only 6 periods but 24 periods in the day.

We analyzed the below periods:

- the morning (8.00 and 12.00 a.m.) in which the sympathetic activity is high;

- the afternoon (16.00 and 20.00 p.m.) in which there is an initial decrease of the sympathetic activity and an increase in the evening; - the night (24.00 and 2.00 a.m.), in this period the parasympathetic activity progressively increases).

With this analysis it is possible to have an idea about the daily cardiovascular neurovegetative pattern of the patients.

Statistical analysis was carried out with SigmaStat software with $\mathrm{p}<0,05$ considered significant.

Patients. We studied 139 patients. 58 Patients were enrolled but only 36 patients ( $17 \mathrm{~F}$ and $19 \mathrm{M}, 73,9 \pm 8,9$ years) completed the study. The dropouts were due to lack of caregivers or errors committed by caregivers during data acquisition. At the patients we installed a pulse for a week.

Results. With these preliminary data we obtained 3 important results: first, in all the patients enrolled we did not observe any change of electrical conduction on the ECG signals and, consequently, we had the opportunity to observe that the neurological therapy did not result in any alteration on this physiological parameter.

Second, the cardiovascular variability is very low in all period considered. In fact the principal indexes of the Heart Variability both in time and frequency domain (SDNN, RMSDD and Total Power) showed a reduction respect to the values considered normal, while the respiratory rate showed no changes during all the period considered. (Tabl. 1).

Finally, in each period considered the both linear in the frequency domain and non linear indexes of the sympathetic activity, showed a marked increase specially during the night period in wich the rest was confirmed by the low HR and the low indexes of the activity level, expressed in arbitrary units, and then it there should be an increase in vagal tone. In fact, in each period observed, the LF/HF ratio in the frequency domain, and non linear indexes SD2/SD1 (Poincaré plot) and $\alpha 1 / \alpha 2$ ratio (Detrended Fluctuation Analysis) showed values greater than 1 expression of sympathetic hiperactivity. (Tabl. 2).

\section{Discussion}

Telemedicine applications play an increasingly important role in health care. They offer indispensable tools for home healthcare, remote patient monitoring, and disease management, not only for rural health and battlefield care, but also for nursing home, assisted living facilities, and maritime and aviation settings. In addiction, multiple comorbid conditions among older patients require

Tabl. 1. The principal indexes of the Heart Variability both in time and frequency domain (SDNN, RMSDD and Total Power).

\begin{tabular}{|l|c|c|c|c|}
\hline hour & $\begin{array}{c}\text { Respiratory rate } \\
\mathbf{b} / \mathbf{m i n}\end{array}$ & $\begin{array}{c}\text { SDNN } \\
\mathbf{m s e c}\end{array}$ & $\begin{array}{c}\text { RMSDD } \\
\mathbf{m s e c}\end{array}$ & $\begin{array}{c}\text { Total Power } \\
\mathbf{m s e c}\end{array}$ \\
\hline 08.00 & $15,8 \pm 2,8$ & $22,7 \pm 8,4$ & $20,7 \pm 8,0$ & $522,2 \pm 357,2$ \\
\hline 12.00 & $16,6 \pm 3,7$ & $24,5 \pm 13,3$ & $22,3 \pm 12,5$ & $682,0 \pm 815,9$ \\
\hline 16.00 & $14,6 \pm 4,6$ & $20,1 \pm 8,0$ & $19,3 \pm 8,2$ & $417,6 \pm 310,7$ \\
\hline 20.00 & $15,1 \pm 4,4$ & $25,3 \pm 17,9$ & $25,1 \pm 24,4$ & $729,5 \pm 1135,3$ \\
\hline 24.00 & $14,0 \pm 4,9$ & $25,8 \pm 17,3$ & $23,0 \pm 17,5$ & $975,4 \pm 1859,4$ \\
\hline 02.00 & $16,8 \pm 3,3$ & $26,1 \pm 16,0$ & $25,4 \pm 13,7$ & $773,0 \pm 1184,0$ \\
\hline
\end{tabular}

The data are expressed as Mean $\pm S D$.

Tabl. 2. The LF/HF ratio in the frequency domain, and non linear indexes SD2/SD1 (Poincaré plot) and a1/a2 ratio (Detrended Fluctuation Analysis).

\begin{tabular}{|l|c|c|c|c|c|}
\hline \multicolumn{1}{|c|}{ hour } & $\begin{array}{c}\text { R-R interval } \\
\text { msec }\end{array}$ & LF/HF & SD2/SD1 & $\alpha \mathbf{1 / \alpha 2}$ & $\begin{array}{c}\text { Activity Level } \\
\text { A.U. }\end{array}$ \\
\hline 08.00 & $880,9 \pm 145,3$ & $2,7 \pm 1,9$ & $2,0 \pm 0,6$ & $2,6 \pm 1,3$ & $5,9 \pm 6,3$ \\
\hline 12.00 & $857,7 \pm 145,2$ & $2,7 \pm 2,3$ & $2,0 \pm 0,9$ & $2,5 \pm 1,1$ & $8,4 \pm 5,2$ \\
\hline 16.00 & $843,9 \pm 127,2$ & $2,5 \pm 2,2$ & $1,9 \pm 0,7$ & $2,4 \pm 0,7$ & $8,0 \pm 7,5$ \\
\hline 20.00 & $851,2 \pm 133,7$ & $2,9 \pm 2,2$ & $2,0 \pm 0,8$ & $2,7 \pm 0,8$ & $5,9 \pm 4,5$ \\
\hline 24.00 & $972,5 \pm 144,1$ & $3,1 \pm 2,6$ & $2,1 \pm 0,7$ & $3,1 \pm 1,0$ & $1,1 \pm 1,6$ \\
\hline 02.00 & $998,4 \pm 136,5$ & $2,6 \pm 3,5$ & $1,8 \pm 0,7$ & $2,7 \pm 1,0$ & $1,1 \pm 1,6$ \\
\hline
\end{tabular}


frequent physician office and emergency room visits, at times leading to hospitalization. In recent years, mobile health systems utilizing hand-held devices (e.g., smartphones or tablet) have been developed, which could be used for health-related interventions. Studies have demonstrated that technological innovation is vital for prosperous economies, and greater technological innovation leads to improved public health indicators. Moreover an optimal model for telemedicine use in the international care setting has not been established

The principal result of this study is the possibility to evaluate from remote not only the ECG signals but also, in post-analysis but in real-time, the behaviour of the neurovegetative assessment of the cardiovascular system during the day and it is possible to couple this aspect with the activity level, the breath frequency and the hearth rate. In this way we can control completely the patients.

The Pulse device performs a real-time recording of physiological signals: A, 1-lead ECG Electrocardiogram; B, Bio-impedance; C, Activity through 3 -axis Accelerometer. The signals are processed online to determine several physiological indexes (RR Hearth rate and Hearth rate Variability, Respiration Rate, Activity Level and Body Posture).

Our objective was to describe a new device for the home, cardiovascular and motor control of the patients with dementia. In fact in this study, although of a pilot nature, we used a new device. The Pulse Device is a wearable electronic, battery operated device that is worn on the chest for the acquisition, recording and transmission of physiological parameters to external devices which can analyze or forward the data to additional storage elements or system. The device uses a disposable fabric adhesive component that attaches to the subject and connects to the enclosed electronic components. The PULSE device is also capable to record symptomatic and asymptomatic events and is indicated for ambulatory monitoring of non-lethal cardiac arrhythmias. Additionally, resident in the Pulse device is a heart rate, respiration rate and activity level calculation algorithm, which allows the system to manage information messages from/to the Server according to specific settings defined by the physicians/operators. The device is a part of a Multiparameter Analysis System, Pulse System and communicates via a Bluetooth ${ }^{\circledR}$ radio link with the external device. Specification of PULSE System is beyond the scope of this document.

The device permits to monitor not only the normal parameters (ECG, respiratory rate or activity level) but also to have a daily behaviour of the neurovegetative cardiovascular pattern related to activity level and respiratory rate. In fact the 4 patients presented in this study show 4 different sympato-vagal system patterns, then it is possible to modify or to adapt the therapy in a personalized way in real time.

In conclusion the proposed system can help the physician and the caregiver in the control of these particular patients. The wireless connection allowed various of device application and several monitoring arrangements ranging from real-time monitoring to longterm recording of biological signals. Implementation of this model may facilitate both accessibility and availability of personalized monitor and therapy. Further studies would validate it in the clinical and healthcare environment.

Transparency.

Declaration of financial/other relationships: None.

Author contributions: none.

\section{References}

1. Akselrod S., Gordon D., Ubel F.A., Shannon D.C., Berger A.C., Cohen R.J. Power spectrum analysis of heart rate fluctuation: a quantitative probe of beat-to-beat cardiovascular control. Science. 1981, vol. 213 (4504), pp. 220-222.
2. Balocchi R., Cantini F., Varanini M., Raimondi G., Legramante J. M., Macerata A. Revisiting the potential of time-domain indexes in short-term HRV analysis. Biomed. Tech., 2006, iss. 51, pp. 190-193.

3. Brennan M., et al. Do existing measures of Poincare plot geometry reflect nonlinear features of heart rate variability? IEEE Trans. Biomed. Eng., 2001, vol. 48, 1342-1347.

4. Kasanuki Iseki E., Fujishiro H., Ando S., Sugiyama H., Kitazawa M., Chiba Y., Sato K, Arai H. Impaired heart rate variability in patients with dementia with Lewy bodies: Efficacy of electrocardiogram as a supporting diagnostic marker. Parkinsonism Relat Disord., 2015, vol. 21, pp. 749-754.

5. Legramante J. M., Sacco S., Raimondi G., Di Lecce V. N., Pallante M., Di Nardo P., Galante A. Investigating feedforward neural regulation of circulation from analysis of spontaneous arterial pressure and heart rate fluctuations in conscious rats. Am. J. Physiol. Heart Circ Physiol., 2009, iss. 296, H202-H210.

6. Lindauer A., Seelye A., Lyons B., Dodge H. H., Mattek N., Mincks K., Kaye J., Erten-Lyons D. Dementia Care Comes Home: Patient and Caregiver Assessment via Telemedicine. Gerontologist, 2017, vol. 57, iss. 1, pp. 85-93.

7. Mäkikallio T. H., et al. Prediction of sudden cardiac death by fractal analysis of heart rate variability in elderly subjects. J. Am. Coll. Cardiol., 2001, vol. 37, pp. 1395-1402.

8. Malliani A., Pagani M., Lombardi F., Cerreti S. Cardiovascular neural regulation explored in the frequency domain. Circulation, 1991, vol. 84, iss. 2, pp. 482-492.

9. Martinmaki K., Rusko H., Saalasti S., Kettunen J. Ability of short-time Fourier transform method to detect transient changes in vagal effects on Hearts: a pharmacological blocking study. Am. J. Physiol. Heart Circ. Physiol., 2006, iss. 290, H2582-H2589.

10. Martynenko A., Yabluchansky M., Kantor B. Mathematical model of automatic nervous systems. Technology and health care: J. Europ. Society for Engineering and Medicine, 2001, iss. 9, pp. 174-176.

11. Raimondi G., Legramante J. M., Scordamaglia B., Masci I., Montanari G., Pampena R., Skroza N., Potenza M. C. Linear and non-linear $R-R$ interval variability analysis in the neurovegetative cardiovascular assessment in Psoriasis and Obesity. Appl. of Inform. Systems in Engineering and Biosci., 2014, pp. 61-69.

12. Raimondi G., Scordamaglia B., Legramante J. M., Montanari G., Skroza N., Potenza M. C. R-R interval analysis in moderate psoriasis. Klin. inform. Telemed., 2013, vol. 10, pp. 189-190.

13. Sindona F., Raimondi G., Pecchia R., Spaziani E., Masci I., Scordamaglia B. The effects of general anesthesia on heart rate variability during abdominal surgery. J. Medicine, Physiol. and Biophysics, 2015, vol. 18, pp.93-99.

14. Williams K., Arthur A., Niedens M., Moushey L., Hutfles L. In-home monitoring support for dementia caregivers: a feasibility study. Clin. Nurs. Res. 2013, vol. 22, pp. 139-150.

15. Yamamoto Y., Nakamura Y., Sato H., Yamamoto M., Kato K., and Hughson R. L. On the fractal nature of heart rate variability in humans: effects of vagal blockade. Am. J. Physiol. Regul. Integr. Comp. Physiol., 1995, iss. 269, R830-R837.

16. Yeragani V. K., Sobolewski E., Kay J., Jampala V. C., Igel G. Effect of age on long-term heart rate variability. Cardiovasc. Res., 1997, vol. 35, pp. 35-42.

\section{Corresponding author}

Gianfranco Raimondi, Associated professor of Internal Medicine «Sapienza» University of Roma, Italy mobile phone: 00393286112942 e-mail: gianfrancoraimondi@uniroma1.it 


\title{
Щоденна оцінка ВСР при деменції, яка вимірюється за допомогою віддаленого контролю
}

\author{
G. Raimondi ${ }^{1}$, N. Marchitto ${ }^{2}$, B. Scordamaglia ${ }^{1}$, A. Ciaramella ${ }^{1}$, P. Casacci ${ }^{3}$ \\ M. Pistoia ${ }^{3}$, S. Sacco ${ }^{1}$, G. Sancesario ${ }^{4}$ \\ ${ }^{1}$ University of Roma «Sapienza», ${ }^{2} \mathrm{ASL}$ Latina, ${ }^{3}$ Liferesult, ${ }^{4}$ University «Tor Vergata», Roma
}

\begin{abstract}
Резюме
Вступ. Використання технологій в якості підтримки та медичної допомоги при різних видах захворювань в даний час $є$ спільною рисою кількох дослідницьких проектів, що проводяться на європейському та національному рівнях. Такі хвороби, як хвороба Альцгеймера або інсульт, які вважаються одними з основних причин інвалідності, знаходяться в центрі цих проектів.

Мета. Мета цього дослідження полягала в тому, щоб оцінити здатність контролювати щоденну вегетативну оцінку у пацієнтів з деменцією за допомогою аналізу ВСР ЕКГ-сигналу, записаного новим пристроїм «Пульс», який $є$ мобільним електронним пристроєм для збору, реєстрації та передача фізіологічних параметрів на зовнішні пристрої.

Матеріали та методи. Ми вивчили 36 пащієнтів (17 жінок (F) і 19 чоловіків (M), 73,9 8,9 років). У пащієнтів встановили «Пульс» на тиждень. По імпульсу можна отримати запис протягом 5 хвилин щогодини, в якій — ЕКГ, частота дихання, положення тіла і рівень активності.

Результати. За попередніми даними отримані 3 важливих результати: по-перше, у всіх пацієнтів, які були включені в дослідження, не спостерігали будь-яких змін електропровідності на сигналах ЕКГ. По-друге, варіабельність серцево-судинної системи дуже низька за весь аналізований період. Фактично основні показники ВСР показали зниження. Однак, в частотної області, в кожному розглянутому періоді, особливо в нічний час, лінійні і нелінійні показники симпатичної активності помітно збільшилися.

Висновок. Запропонована система може допомогти лікарю і особі, яка здійснює догляд, контролювати цих пацієнтів з деменцією. Бездротове з'єднання дозволило використовувати різні пристрої і кілька пристроїв моніторингу, починаючи від моніторингу в режимі реального часу до довгострокової записи біологічних сигналів. Реалізація цієї моделі може полегшити як доступність персоналізованого монітора, так і доступність терапії. Подальші дослідження підтвердять це в клінічній практищі і медичному середовищі.
\end{abstract}

\section{Ежедневная оценка ВСР при деменции, измеряемая удаленным контролем}

\author{
G. Raimondi ${ }^{1}$, N. Marchitto ${ }^{2}$, B. Scordamaglia ${ }^{1}$, A. Ciaramella ${ }^{1}$, P. Casacci ${ }^{3}$ \\ M. Pistoia ${ }^{3}$, S. Sacco ${ }^{1}$, G. Sancesario ${ }^{4}$ \\ ${ }^{1}$ University of Roma «Sapienza», ${ }^{2}$ ASL Latina, ${ }^{3}$ Liferesult, ${ }^{4}$ University «Tor Vergata», Roma
}

\begin{abstract}
Резюме
Введение. Использование технологий в качестве поддержки и медицинской помощи при различных видах заболеваний в настоящее время является общей чертой нескольких исследовательских проектов, проводимых на европейском и национальном уровнях. Такие болезни, как болезнь Альцгеймера или инсульт, которые считаются одними из основных причин инвалидности, находятся в центре этих проектов.

Цель. Цель этого исследования состояла в том, чтобы оценить способность контролировать ежедневную вегетативную оценку у пащиентов с деменцией с помощью анализа ВСР ЭКГ-сигнала, записанного с помощью нового устройства: «Пульс», которьй является носимым электронным устройством для сбора, регистрации и передача физиологических параметров на внешние устройства.

Материалы и методы. Мы изучили 36 пациентов (17 женщин (F) и 19 мужчин (M), 73,9 8,9 года). У пациентов установили «Пульс» на неделю. По импульсу можно получить запись в течение 5 минут каждый час, в которой - ЭКГ, частота дыхания, положение тела и уровень активности.

Результаты. С этими предварительными данными получены 3 важных результата: во-первых, у всех пациентов, которые были включены в исследование, не наблюдали каких-либо изменений электропроводности на сигналах ЭКГ. Во-вторых, вариабельность сердечно-сосудистой системы очень низкая за весь рассматриваемый период. Фактически основные показатели ВСР показали снижение. Однако, в частотной области, в каждом рассматриваемом периоде, особенно в ночное время, линейные и нелинейные показатели симпатической активности заметно увеличились.

Заключение. Предлагаемая система может помочь врачу и лицу, осуществляющему уход, контролировать этих пациентов с деменщией. Беспроводное соединение позволило использовать различные устройства и несколько устройств мониторинга, начиная от мониторинга в режиме реального времени до долгосрочной записи биологических сигналов. Реализация этой модели может облегчить как доступность персонализированного монитора, так и доступность терапии. Дальнейшие исследования подтвердят это в клинической и медицинской среде.
\end{abstract}

Ключевые слова: телемедицина; ВсР; деменция. 